DOI: https://doi.org/10.34069/AI/2021.44.08.9 How to Cite:

Musychenko, O., Streltsov, Y., Kozachenko, O., Vasyliaka, O., \& Chornozub, L. (2021). Intelligibility of a criminal law: Theoretical and practical aspects. Amazonia Investiga, 10(44), 92-102. https://doi.org/10.34069/AI/2021.44.08.9

\title{
Intelligibility of a criminal law: Theoretical and practical aspects
}

\section{Зрозумілість кримінального закону: теоретичні та практичні аспекти}

Received: May 12, 2021

The main task of the article is to study a separate qualitative property criminal law its intelligibility. When solving the problem the definition of intelligibility of the criminal law taking into account genesis is formulated this concept and different approaches to its content, which have developed in modern law doctrine. In order to substantiate the author's approach to the definition of intelligibility of the criminal law the monitoring of normative-legal acts, decisions of national and international judicial authorities is carried out.

It is shown that the term 'intelligibility of law' and related terms 'clear', 'precise', 'simple' law are actively used both in regulations and in decisions of national and international judicial authorities. However, the terminology is diverse, thereby it has been suggested in the decisions of the European Court of Human Rights to use the term 'intelligibility' of the law, which is the most accurate and adequately reflects the assessment of the legal certainty of national laws.

The general conclusion is substantiated that in modern doctrine there are three approaches to
Accepted: July 29, 2021

Written by:

Olha Musychenko ${ }^{36}$

https://orcid.org/0000-0001-6171-710X

Yevgen Streltsov ${ }^{37}$

https://orcid.org/0000-0001-8156-0285

Oleksandr Kozachenko ${ }^{38}$

https://orcid.org/0000-0002-8412-8639

Olesya Vasyliaka ${ }^{39}$

https://orcid.org/0000-0002-1280-2743

Larysa Chornozub ${ }^{40}$

https://orcid.org/0000-0002-2819-9192

\section{Анотація}

Основним завданням статті $є$ дослідження окремої якісної властивості кримінального закону - його зрозумілості. При вирішенні поставленого завдання сформульована дефініція зрозумілості кримінального закону 3 урахуванням генезису даного поняття та різних підходів щодо його змісту, які склалися в сучасній правовій доктрині. 3 метою обгрунтування авторського підходу до дефініції зрозумілості кримінального закону здійснений моніторинг нормативно-правових актів, рішень національних та міжнародних судових органів.

Показано, що термін «зрозумілість закону» та суміжні 3 ним терміни «чіткий», «точний», «простий» закон активно використовуються як в нормативно-правових актах, так і в рішеннях національних та міжнародних судових органів, що пов'язано 3 великою увагою до правової визначеності як складової верховенства права. Однак, термінологія $\epsilon$ різноманітною, у зв'язку з чим запропоновано в рішеннях Європейського суду $з$ прав людини використовувати термін

\footnotetext{
${ }^{36} \mathrm{PhD}$, Senior Lecturer of the Department of Criminal Law and other criminal and legal studies of the Mykolaiv Institute of Law National University «Odessa Academy of Law» (Mykolaiv, Ukraine).

${ }^{37}$ Doctor of Law, Doctor of Theology, Professor, Corresponding Member of the National Academy of Legal Sciences of Ukraine, Honored Scientific Worker of Ukraine, Head of the Criminal Law Department at National University "Odessa Law Academy" (Odessa, Ukraine).

${ }^{38}$ Doctor of Law, Professor, Head of the Department of Criminal Law and other criminal and legal studies of the Mykolaiv Institute of Law National University «Odessa Academy of Law» (Mykolaiv, Ukraine).

${ }^{39}$ Candidate of Law, Associate Professor of the Department of Criminal Law and other criminal and legal studies of the Mykolaiv Institute of Law National University «Odessa Academy of Law» (Mykolaiv, Ukraine)

${ }^{40}$ Candidate of Law, Associate Professor of the Department of Criminal Law and other criminal and legal studies of the Mykolaiv Institute of Law National University «Odessa Academy of Law» (Mykolaiv, Ukraine).
} 


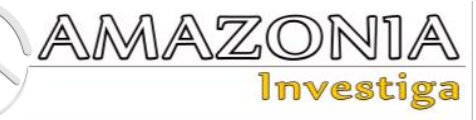

determining the legal nature of the intelligibility of the law: as a component of the rule of law, as a requirement for the language of law, as a qualitative property of law. The absence of antagonistic features in each of the approaches allowed to use the positive gains of different perceptions of the intelligibility of the criminal law and to define it.

Key word: legal certainty, intelligibility of law, intelligibility of a criminal law, clear law, precise law, simple law.

«зрозумілість» закону, який змістовно $\epsilon$ найбільш точним, і таким, який адекватно відображає оцінку реалізації правової визначеності національних законів.

Обгрунтовано узагальнюючий висновок, що у сучасній доктрині виділяється три підходи щодо визначення правової природи зрозумілості закону: як складова принципу верховенства права, як вимога до мови закону, як якісна властивість закону. Відсутність антагоністичних ознак у кожного 3 підходів дозволила використати позитивні надбання різного сприйняття зрозумілості кримінального закону і надати їі дефініцію.

Ключові слова: правова визначеність, зрозумілість закону, зрозумілість кримінального закону, чіткий закон, точний закон, простий закон.

\section{Introduction}

Problems related to the study of the essential and applied properties of legal acts are gaining special importance in the twenty-first century, and in many countries around the world. And this is due not only to the further active development of legislation, increasing the amount of legal material through the efforts of states to regulate as much as possible public relations, but also the awareness of the need to comply with their quality. It is high-quality legal acts that can fully solve the tasks set before them and influence public relations in a useful direction for civil society, that is to ensure the effectiveness of legal regulation. Since one of the main purposes of criminal law is to prevent the commission of criminal offenses by a particular person and by all persons subject to criminal law prohibitions, the criminal law must be (set out and drafted) so that it can be perceived, understood and to understand all citizens who are carriers of criminal capacity. This raises the question of the intelligibility of the criminal law, which provides for the possibility of applying the strictest of all legal - criminal law measures.

Thus, the purpose of the article is to study the intelligibility of criminal law as its separate qualitative property and analyze regulations, decisions of national and international judicial bodies in terms of intelligibility of law.

\section{Literature Review}

The approach to determining the intelligibility of criminal law is based on the cultural and anthropological dimension of criminal law (Kozachenko and Musychenko, 2015). The

reference of the legislation first of all determines high standards for the quality of criminal law, providing it with such properties that will promote its full 'assimilation' by individuals, and thus it will be able to maximize the preventive effect.

The question of the intelligibility of the criminal law was not directly considered in science, although this problem was touched upon by scientists who studied the problems of the criminal law, its properties and features (Shargorodskii, 1948; Romanov, 2015), the hermeneutics of the criminal law (Zaginej, 2015; Pycheva, 2006). Recently, the publications of theorists and practitioners have become more frequent, in which attempts are made to find out how the intelligibility of the law relates to the related concepts of intelligibility, accuracy, simplicity, accessibility (Caussignac, 2005; Boyd, 2015), because sometimes they all like will be shown later in the article, in practice are considered as single-order, and there is no established definition of not only the intelligibility of the criminal law, but also the law in general.

Since the concept of 'intelligibility of a criminal law' is closely related to the category of 'understanding', which has a complex nature, the theoretical basis for its study were works not only in the field of criminal law but also work on the hermeneutics of law (Dudash, 2010; Dudchenko, 2014; Ovchinnikov, 2002) of psycholinguistics (Vekker, 1998; Ovsienko, 2013). 


\section{Methodology}

During the writing of the article, general scientific and special methods of cognition of legal phenomena were used. In order to achieve this goal, the authors used the following methods of scientific knowledge: historical, comparative law, logical-semantic and logical-legal.

The historical method was used in the analysis of the historical aspect of the approach to the intelligibility of the law; comparative law when comparing the terminology used in laws and other regulations of different countries; logicalsemantic and logical-legal method was used to conduct an in-depth study and formulation of the author's concept of intelligibility of a criminal law.

\section{Results and discussion}

\section{Historical aspect of the intelligibility of the law}

The intelligibility of the laws was discussed in Roman law: 'this inviolable law it must be made clear to all people so that it becomes clear to them how significant confusion and absolute uncertainty to what moderation and in accordance with the laws the truth they came' (paragraph 13, III Constitution 'Tanta' Digests of Justinian on the compilation digests), 'laws, being clear and understandable, easily penetrate the soul' (paragraph 2, II Constitution 'Omnem' Digests of Justinian on the compilation of digests) (Kophanov, 2008).

Historical analysis shows that intelligibility of laws has not always been considered as a defining qualitative, inherent in the law characteristic, so we can point to two approaches that have developed in science. The first is that there is intelligibility of laws their necessary property must be ensured by accuracy, simplicity in them writing, because the state has the right only then to demand compliance by citizens prescriptions when they are intelligible to them. Within the second direction of understanding to intelligibility is approached as a declarative characteristic because of the intelligibility of the law it is impossible to achieve due to the subjective peculiarities of comprehension of the content of the text of the law by all citizens.

The doctrinal principles of the study of the intelligibility of criminal law in a positive aspect can be found in ancient thinkers who paid considerable attention to the characteristics of the law. His contribution to the development of rules for constructing laws, among which considerable attention was paid to intelligibility, made by philosophers, lawyers who operated in the sixteenth-eighteenth centuries. Thus, the justice of the law utopian T. Mor associated with its simplicity and comprehensibility for citizens (Mor, 1935), Ch. Bekaria in the work 'On Crimes and Punishments' (1764) sharply spoke about the need to comply with the 'letter of the law', he believed that no nothing more dangerous than to act in the spirit of the law, was a supporter of strict observance of the law without any derogations (Beccaria, 2004), Sh. Montesquieu stressed the importance of quality laws aimed at protecting the most important values - life, honor, property (Montesquieu, 1956), indicating to the increased attention to intelligibility of the criminal law.

The existence of such categorical statements about the need to follow the exact 'letter' of the law is a consequence of the fact that in the field of criminal law at that time there was a certain legal uncertainty, which gave rise to oppression of citizens, state and legal voluntarism. This was the impetus for the formation of new, sometimes quite radical views on the properties of written law.

Many of the provisions in the works of these thinkers formed the basis for the formation of knowledge in a particular area - the legislative technique. The work of ancient philosophers, who linked the clear presentation of norms with the accuracy, simplicity, accessibility of their language, continued to be detailed by theorists within a particular area of law - legal linguistics, and scholars who studied the legal technique of criminal law and hermeneutics of this legal act.

In contrast to this widespread, long-established approach, German legal doctrine in the nineteenth century somewhat refuted the postulate that laws should be understandable to all citizens, and argued that ordinary citizens would not be able to understand the legal text because and law enforcement requires legal education. R. von Yeering, who insisted on the simplification of law, at the same time argued that to understand it, you need 'a peculiar ability to perceive, a special art of abstract thinking, legal intuition and imagination', 'skill in dealing with legal concepts' (Iering, 2008), and F.K. von Savigny pointed out that in order to fully understand the content of a law, we must identify the grammatical rules used by the legislator, the logical connection between the individual parts of the law, understand what was added to the law by this law, and find out how the law relates to the whole legal system and how it should be 


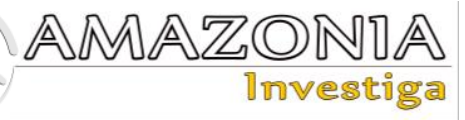

effectively combined with it (Savigny, 2011). Even today, there are still supporters of this approach among theorists (for example, Kolmakova, 2009; Assy, 2011) and representatives of the theory of criminal law, who consider unattainable and imaginary clarity and accessibility of the law, and its understanding should be provided not by increasing the requirements of the law, but through the interaction of law enforcement and user in the implementation of criminal law (Sitnikova, 2016). However, the latter are not many, their views are more related to the statement of the existence of incomprehensible provisions in the law, finding ways out of this situation, rather than a complete denial of the existence of clear laws, and finding ways to ensure such a property.

In addition to the above, historical facts show that the incomprehensibility, confusion of laws, their purpose 'for the elect' was used by the ruling elite for their own anti-social purposes (for example, criminal law of the early Soviet period, Nazi Germany and so on), as evidenced by authors (Musychenko, 2020) and research by other scientists (Borisova, 2012; Ermakoff, 2020). Therefore, the intelligibility of laws should still be seen as a conscious necessity in a civilized democratic society.

\section{Intelligibility of a criminal law in national and international practice}

Given that the intelligibility of the law is primarily related to the principle of the rule of law, this term is actively used both in regulations and in decisions of national and international courts.

The term 'intelligibility' is beginning to be actively used in the regulations of various states and supranational entities in the early twentyfirst centuries, which is associated with a certain rethinking of the components of the rule of law.

Thus, the Rule of Law Report, approved by the Venice Commission at its eighty-sixth plenary session (2011, Venice, March 25-26), for the first time attempts to generalize terms known to different national laws to denote concepts that are not always synonymous with the rule of rights: the German concept of 'rechtsstaat', the Portuguese 'estado de direito', the French 'etat de droit' (or a term used by the Council of Europe: 'prééminence du droit'), the Russian concept of 'rule of law'. The report takes as a basis the definition given by Tom Bingham in 2010, and from it in paragraph 37 derives eight components of the rule of law, among which one of the first is accessibility of the law (that it be intelligible, clear and predictable). Based on this definition, as well as taking into account the concept of the rule of law in different legal systems, paragraph forty-one defines the components of the rule of law: (1) Legality, including a transparent, controlled and democratic process of enactment of laws; (2) Legal certainty; (3) Prohibition of arbitrariness; (4) Access to justice by independent and impartial courts, including judicial review of administrative acts; (5) Respect for human rights; (6) Non-discrimination and equality before the law.

Revealing the component of legal certainty, the report highlights the following provisions that are important for the disclosure of the concept of intelligibility: the state must make the text of the law easily accessible; the law has to be formulated with sufficient precision to enable the individual to regulate his or her conduct) (paragraph forty-four); legal certainty requires that legal rules are clear and precise, and aim at ensuring that situations and legal relationships remain foreseeable) (paragraph forty-six); parliament shall not be allowed to override fundamental rights by ambiguous laws (paragraph forty-seven). As we can see, in the context of disclosure of legal certainty, the emphasis is on an accessible, clear, precise, unambiguous law. And to assess the state of the rule of law in accordance with these and other characteristics in individual states, the annex to the report indicates a checklist, including questions: 'Are the laws written in an intelligible language?' (Venice, 2011), that is, the term 'intelligibility' is a general qualitative characteristic of the language of laws that meet the requirements of accessibility, precision, clarity, unambiguity. This proves that intelligibility is a general property of the law and a broader concept than the requirements of accuracy, clarity, accessibility, simplicity of the language of the law.

The realization that intelligibility is a component of the rule of law and depends on the language requirements for the law defined above has given impetus in recent times to the authorities' meticulous attention to legal language in general, to documents developed by the authorities. For example, in the United States in 2010 passed a law on simple writing, "the purpose of this Act is to improve the effectiveness and accountability of Federal agencies to the public by promoting clear Government communication that the public can understand and use' (Law 274, 2010). This 
law introduced the concept 'plain writing'; the law requires federal executive agencies (agencies) to use plain language in any document that is necessary to obtain any benefits or services from the federal government, or that explains to the public how to comply with federal government requirements; according to it 'Plain language' (2011) are developed. Although this law does not apply directly to regulations, the need for their quality is mentioned in an executive orders 'Regulatory Planning and Revision' (Order 12866, 1993): Americans deserve a regulatory system that works for them, not against them, particularly regulations that are effective, consistent, sensible, and understandable; each agency shall draft its regulations to be simple and easy to understand, with the goal of minimizing the potential for uncertainty (paragraph twelve). The 2011 'Improving Regulation and Regulatory Review' decree states that the regulatory system should promote predictability and reduce uncertainty, it must ensure thatregulations are accessible, consistent, written in plain language, and easy to understand (Order 13563, 2011).

The available form of legal documents and information provided to the subjects of legal relations, the use of clear and understandable language are among the documents adopted by the European Union: article fifty-seven Council Regulation (EU) 2017/1939 of 12 October 2017 implementing enhanced cooperation on the establishment of the European Public Prosecutor's Office ('the EPPO')), directive (EU) 2016/680 of the European Parliament and of the Council of 27 April 2016 on the protection of natural persons with regard to the processing of personal data by competent authorities for the purposes of the prevention, investigation, detection or prosecution of criminal offences or the execution of criminal penalties, and on the free movement of such data, and repealing Council Framework Decision 2008/977/JHA, article seven, five Regulation (EU) 2016/679 of the European Parliament and of the Council of 27 April 2016 on the protection of natural persons with regard to the processing of personal data and on the free movement of such data (Council of the European Union, 2019), and so on. In addition, Inclusion Europe has created European standards for making information easy to read and understand (Inclusion Europe, 2009).

The term 'intelligibility' is used and the related requirements for legislation, court decisions directly in the laws of individual states, and recently it is becoming more active. For example, in Art. 300 of the Criminal Procedure Code of
Ukraine states that if the court decision is incomprehensible, the court that passed it, its decision explains its decision, without changing its content (Code of Ukraine 4651-VI, 2012). The emphasis on the fact that the content of the norm is identified with reality and depends on human linguistic established practice is made in the Civil Code of Spain, in accordance with Part 1 of Art. 3 which, among other things, 'norms must be interpreted according to the correct meaning of their words' (Real Decreto BOE-A1889-4763, 1889).

Of course, greater attention is paid to the intelligibility and comprehensibility of those laws that establish measures related to deprivation of liberty. In most countries, the application of criminal law by analogy is prohibited, as indicated in the laws themselves, which is why the doctrine of criminal law develops specific tools that should be used in lawmaking to ensure the accuracy and intelligibility of criminal law. In addition, at the legislative level in one of the last adopted criminal codes, the Criminal Code of the Kyrgyz Republic enshrined the principle of legal certainty, in Part 2 of Art. 3 states: 'Criminal law must clearly and clearly define the punishable act (action or omission) and is not subject to expanded interpretation' (Criminal Code of the Kyrgyz Republic, 2017). Countries that reform criminal law are on a similar path of normative consolidation of the components of legal certainty, including the intelligibility of criminal law. Thus, Ukraine is preparing a draft of a new Criminal Code, in which the developers want to enshrine the principle of legal certainty and formulate the following rule: 'The provisions of the Criminal Code must meet sufficient clarity, intelligibility and predictability to allow a person to know in advance which acts are criminal and which criminal -legal means provided for their commission' (Criminal Code of Ukraine (draft), 2021).

An analysis of law enforcement practices shows that both international and national courts are actively addressing issues related to intelligibility and incomprehensibility of legislation.

Thus, the analysis of the decisions of the European Court of Human Rights shows that the Court pays attention to the investigated nature of the laws in its decisions on the appeal of violations of Art. 7 and Art. 10 of the Convention for the Protection of Human Rights and Fundamental Freedoms, which interprets both the articles as a whole and the specific provisions they apply: 'constituted a criminal offense in 


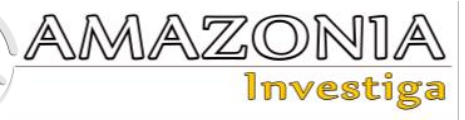

accordance with the general principles of law', 'rights established by law and necessary in a democratic society'. The judgments of the European Court of Human Rights state qualitative requirements, in particular regarding the predictability of the law: it must be sufficiently accessible, precise, clear (Novik v. Ukraine, Baranowski v. Poland, Khudoyorov v. Russia, SW v. The United Kingdom, Kokkinakis v. Greece, Ruban v. Ukraine, Mueller and others v. Switzerland, Salov v. Ukraine, Pasko v. Russia) (European Court of Human RightsHudoc, database). It is emphasized that the degree of manifestation of the qualitative characteristics of national legislation largely depends on the content of the contested law, the area in which it is intended to cover. If national law allows for the possibility of deprivation of liberty, it must have the highest level of accuracy and intelligibility, be foreseeable to eliminate any risk of arbitrariness. At the same time, the ECHR understands the 'law' in the 'substantive' rather than the 'formal' sense. Thus, it includes everything that constitutes written law, including acts that have less legal force than laws, as well as court decisions in which their interpretation is given. Such an understanding of the law, as shown by the analysis of the case law of the ECHR, often leads to the refusal to satisfy the applicants' complaints of violation of Art. 7 and 'predictability of the law' paragraph 2 of Art. 10 of the Convention.

The analysis also showed that different terms are used in ECHR decisions to denote qualitative requirements for the law, including criminal law. Today, the case law of the ECHR in the countries that have acceded to the Convention is a model and reference point for national judicial bodies, recognized as a source of law. In some countries, the law stipulates that the case law of the ECHR national courts are obliged to apply in cases, use as a source of law (Law of Ukraine 3477-IV, 2006). In addition, in accordance with Art. 1 of Protocol №16 to the Convention of 02.10.2013, the higher judicial institutions of the member states may apply to the Court for advisory opinions on fundamental issues concerning the interpretation or application of rights and freedoms. This requires a certain unification of the terminology used in the decisions of the ECHR. As the purpose of the above-mentioned Report of the Venice Commission was to set out a generally accepted clear understanding of the rule of law, so that international organizations as well as national and international courts could interpret and apply this fundamental value, we believe that the ECHR can actively use the term 'intelligibility of a law' as the most common for assessing the certainty of rights and offenses in national laws.

Recognition by international institutions of the requirements for national laws designed to ensure its intelligibility - one of the criteria for the rule of law - has led to situations where the highest competent bodies of states are increasingly complaining about the inconsistency of certain laws of intelligibility. For example, a complaint to the Constitutional Council of France about the lack of intelligibility and comprehensibility of the Law on Social Modernization, which violates these requirements to a number of articles of the Labor Code arising from Article 34 of the French Constitution (Resolution No. 2001-455, 2002), a complaint to the Constitutional Tribunal of Poland 24 of the Law on Public Procurement, which contains vague, inconsistently used criteria that violates the constitutional principles of public confidence in the state and the laws it adopts and the proportionality and specificity of the law, which is the accuracy and unambiguousness of its provisions (Public procurement, 2013), the Constitutional Court of Ukraine 7 h. 2 st. 42 of the Law of Ukraine 'On Higher Education' of the principle of legal certainty (Sentencia No. 2-r, 2017), as the term 'dictatorial laws' used in this provision is unclear, there are no criteria to be followed in its interpretation and others.

Quite a number of similar complaints concerning criminal law, for example, the complaint to the Constitutional Tribunal of Poland for noncompliance with the requirements of intelligibility and accuracy of Art. $115 \S 21$ of the Criminal Code of Poland, which contains vague and ambiguous concepts that do not comply with Part 1 of Art. 42 of the Constitution of Poland (Constitutional Tribunal of Poland, 2015), a complaint to the Constitutional Tribunal of Poland on the inconsistency of Art. 56 of the Criminal Tax Code, Art. 42 of the Constitution of Poland, as the relevant provisions of this Code must be defined fully, precisely and unambiguously, constructed correctly both linguistically and logically, which means the obligation to create clear and understandable regulations (Dorothy G. SK 13/05, 2005), a complaint to the Constitutional Tribunal of Poland Art. 97 of the Code of Misdemeanors, the requirement of specificity of the law, which obliges the subject creating the legal norm to make it clear, clear, unambiguous and clear to the addressees of this norm (Constitutional Tribunal of Poland), the petition to the Constitutional Court of Ukraine on inconsistency of Article 
368-2 of the Criminal Code Of the Constitution of Ukraine, including legal certainty (Sentencia No. 1-r, 2019), the petition to the Constitutional Court of Ukraine on Art. 375 of the Criminal code of Ukraine (Sentencia No. 7-r, 2020) in which the estimation concept 'knowingly unjust' is used, the maintenance of which is not defined by the legislation that doesn't provide predictability of application of this article.

It should be noted that despite the growing number of complaints of violations of legal certainty due to the existence of unclear, ambiguous rules prescribed by law, the relevant higher authorities in different countries mostly refuse to satisfy them, arguing that the use of unclear and evaluative concepts in laws, if their meaning can be determined without violating the principle of legal certainty. Only occasionally, due to non-compliance with these requirements, the higher judicial bodies of the states repeal the relevant legislative provisions if they are insufficiently clear, unambiguous, and therefore understandable. For example, the Constitutional Court of Ukraine recognized Articles 368-2 and 375 of the Criminal Code of Ukraine as not meeting the requirement of legal certainty as a component of the constitutional principle of the rule of law, as the dispositions of these norms are insufficiently clear and allow ambiguous understanding.

\section{The concept of the intelligibility of a criminal law}

The concept of intelligibility in modern doctrine is addressed from different positions, emphasizing the following.

First, intelligibility is considered in the context of the components of the rule of law. In modern realities, the intelligibility of the law, especially criminal law, is perceived by scholars as one of the guarantees of the principles of legal certainty (the law must be clear, citizens must understand it to comply (Seryogin, 2014)), equality (can only be ensured with equal understanding and interpretation (Pogrebnyak, 2009)), legality (wording hinders political machinations and the use of the law against the people (Borisova, 2012), justice (because the justice of the law is associated not only with the criminal law measures defined in it, but also with its textual orientation to all without exception (Kozachenko, Vasyliaka, Chornozub \& Musychenko, 2020; Kozachenko, Sotula, Biblenko, Giulyakov \& Bereznikov, 2021), which are based on the fundamental rule of law. This approach is due to the understanding of the components of the rule of law, formed in practice, which was shown above in this article.

Second, while not denying the achievements regarding the intelligibility of the law as a component of the principle of legal certainty, another group of scholars develops the view that intelligibility is one of the mandatory requirements for the language of the law. It is also a fairly common approach, it is further developed in jurisprudence within the general direction formed by the international community, 'Plain language'. Its proponents mostly study the problems of legal technique, and understand intelligibility in different ways: as a means of achieving the principles of verbal organization of regulations; as one of the requirements for the language of the law; as one of the general rules of formulation of normative prescriptions; as a criterion for assessing the qualitative characteristics of regulations. Within the framework of this approach, the language problems of the law are mostly considered.

Third, the concept of clarity is reduced to the necessary qualitative properties of the law, because only a set of appropriate means, methods, rules of legal technique, can adequately express the will of the legislator, makes the law intelligible and therefore effective way of legal regulation of public relations. This is a broader concept than just a requirement for the language of the law, because through the use of certain tools that must meet the requirements of accuracy, brevity, unity of terminology, simplicity and accessibility of presentation, the law is intelligibile. We support the latter approach because it allows a clear distinction between terminology, namely 'language accessibility', 'precisely', 'clarity', 'simplicity' of the law and 'intelligibility' of the law.

Thus, we define the intelligibility of a criminal law as a qualitative property of this legal act, which consists in the maximum proximity of the content of the text of the criminal law laid down by the legislator, drawn up by appropriate legal techniques, to the internal interpretive text of criminal law, and also those entities that are their potential participants.

From the proposed definition it can be seen that intelligibility is interpreted much more broadly than just the linguistic accessibility of the text for most citizens. Intelligibility in our understanding is a certain property that is characteristic of qualitative law. The highest degree of intelligibility is not when the read criminal law prescription becomes easily understood by all 


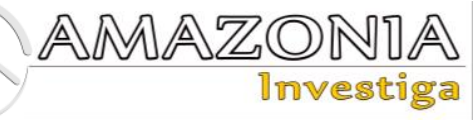

subjects (simplicity, linguistic accessibility), but when with the application of specific rules of interpretation of the criminal law, which tend to be linguistic, the subjects comprehend through symbolic communication the content of the criminal law, and this content corresponds exactly to what the legislator laid down when formulating the norm, that is the law becomes intelligible.

Based on the proposed concept of intelligibility of a criminal law, we can identify the features that make up its content.

First, intelligibility is a qualitative property of criminal law, which, among others, allows us to talk about its effectiveness, because the quality of criminal law is a system of inherent social properties that reflect its social adequacy, and special legal properties that together determine the effectiveness criminal law influence. This feature indicates the essence of the concept under study, as it allows to focus on belonging to the group of legal properties of criminal law, to distinguish it from belonging to the principles, language requirements, criteria and so on.

Secondly, this property is the maximum proximity of the texts of communication: the text of the law and the text of interpretation. The use of the phrase 'maximum proximity' emphasizes that this internal interpretive text (the result of clarification) depends on many factors - age, experience, education, culture, language practice, so it is impossible to achieve a complete coincidence of texts, understanding the text of the law exclusively by all subjects is an unattainable goal. In this aspect of great importance is legal education, legal culture of the population. Since intelligibility is the result of the understanding of many people, the considered property is dynamic. Therefore, the criteria of perception of the text, the clarity of the criminal law should be focused on the average person.

Third, the term 'internal interpretive text' used in the definition is used to denote the result of the perception and awareness of the subjects of the textual unit of the criminal law. Clarity is manifested in the positive result of understanding as an element of hermeneutics, so it is automatically a matter of clarification - the stage of interpretation, the result of which is expressed in the reverse, interpretive internal (selfclarification) text of criminal law.

Fourth, intelligibility is ensured by the proper linguistic and structural design of the criminal law, as the transfer of legislative will to textual communication takes place through the appropriate means of legal technique. The chain of this communication (law - lex - man, or the content of the criminal law - its textual design the internal interpretive text of the subject) should not be interrupted or distorted, and this is facilitated by legal techniques aimed at precise and clear transmission of legislative will. Imbalance in any part of this chain is an undesirable phenomenon. And if there are violations in the first link, of course, in the second, due to subjective factors, they are even more pronounced. The most precise implementation of the legislative will determines the accuracy of the next 'decoding' of the text. Therefore, for the appropriate identical reverse translation of the text, which will be known to a wide range of subjects, it is important to strictly follow the rules of the legal technique of criminal law, which are the key to its clarity and lie primarily in human language practice.

To understand a legal norm is to find out its true meaning. Hence the question of the truth of the content. On the one hand, the objectivity of the norm is reflected in its text, ie the legislator conveys his will by means of language. An objective, true norm will be when the words, their organization in the sentence precisely conveys its meaning. On the other hand, as a result of the interpretation of the norm by the subjects of perception and understanding of the text, the result of clarification (internal interpretive text) is as close as possible to the content of the norm.

Hence the conclusion that to achieve a qualitative property - the intelligibility of criminal law, on the one hand, should take into account the principles, rules, techniques, means of legislative technique of criminal law, compliance with which ensures the appropriate transfer of information, on the other - should take into account rules interpretation (clarification) of the text of the criminal law, taking into account the specifics of the subjects covered by the criminal law (and this is the subjects of criminal law, and their potential participants), so that the result of their interpretation as much as possible corresponded to the established meaning.

\section{Conclusions}

Monitoring of practice has shown that the term 'intelligibility', as well as the related characteristics of 'clear', 'precise', 'simple' law are actively used both in regulations and in decisions of national and international courts. Given our proposed definition, we believe that 
the ECHR can use in its decisions the concept of 'intelligibility' of the law as a more general concept and one that conveys an assessment of the implementation of the legal certainty of national laws.

Analysis of court decisions on complaints about incomprehensibility of certain provisions of criminal law as a violation of the principle of legal certainty showed that, noting vaguely defined and evaluative concepts in the criminal laws of states, courts do not consider it an absolute condition for declaring such norms inconsistent with constitutional principles. In this regard, in the context of reforming the criminal law of some European countries, we consider it a good practice to enshrine at the regulatory level the principle of legal certainty and its component - the intelligibility of criminal law as a guide for the legislator in formulating criminal law.

The study of different points of view on the category of comprehensibility in the theory of law allowed to distinguish three groups of main directions to the studied concept: the first intelligibility as a component of the principle of the rule of law; the second - intelligibility as one of the requirements for the language of law, as one of the rules of formulation of regulations, as a criterion for assessing the qualitative characteristics of regulations; third intelligibility as a necessary qualitative property of the law, which depends on the proper use of legal techniques. Within the latter approach, the following definition was formulated: intelligibility of a criminal law is a qualitative property of the criminal law, which consists in the maximum proximity of the content of the text of the criminal law laid down by the legislator, drawn up by appropriate legal techniques, to the internal interpretive text of the subjects of criminal law relations, are their potential participants.

\section{Bibliographic references}

Assy, R. (2011). Can the Law Speak Directly to its Subjects? The Limitation of Plain Language. Journal of law and society, 38(3). DOI: $10.1111 / \mathrm{j} .1467-6478.2011 .00549 . \mathrm{x}$

Beccaria, Ch. (2004). On crimes and punishments, ed. V.S. Ovchinsky. Issue VI. Moscow: INFRA.

Borisova, T.I. (2012). The Legitimacy of the Bolshevik Order, 1917-1918: Language Usage in Revolutionary Russian Law. Review of central and east european law, 37(4), pp. 395-419. DOI: 10.1163 / $092598812 \mathrm{X} 13274154887024$
Boyd, J.P. (2015). Legislative Intelligibility and the Rule of Law. Justice Issues, 16. Recovered from: http://www.slaw.ca/2015/01/16/legislativeintelligibility-and-the-rule-of-law/.

Caussignac, G. (2005). Clear Legislation. Canada's system of justice. Recovered from: https://www.justice.gc.ca/eng/rp-pr/csjsjc/ilp-pji/cl-lc/index.html.

Code of Ukraine 4651-VI, Criminal Procedure Code of Ukraine. Verjovna Rada de Ucrania, 2012. Recovered from: https://zakon.rada.gov.ua/laws/show/465117\#Text

Constitutional Tribunal of Poland. A constitutional complaint to review the compliance of Art. $115 \S 21$ of the Act of June 6, 1997 - Penal Code under Art. 31 sec. 3 in connection with Art. $41 \mathrm{sec} .1$ and art. 2 and art. $42 \mathrm{sec} .1$ of the Polish Constitution, 2015. Recovered from: https://trybunal.gov.pl/s/sk-4713 .

Constitutional Tribunal of Poland. Sanction for failure by the owner or holder of the vehicle to indicate who he entrusted the vehicle to drive or use at the time when the recording equipment revealed an offense committed by the driver of the vehicle. Entity initiating the proceedings: the Public Prosecutor General. Recovered from: https://trybunal.gov.pl/s/k313

Council of the European Union (2019). European Union instruments in the field of criminal law and related texts. Recovered from: https://www.consilium.europa.eu/media/419 18/eu-instruments-in-the-field-of-criminallaw-and-related-texts_december-2019.pdf

Criminal Code of the Kyrgyz Republic, Ministry of Justice of the Kyrguise Republic de fecha 2 de febrero de 2017 . Recovered from: http://cbd.minjust.gov.kg/act/view/ru$\mathrm{ru} / 111527$.

Criminal Code of Ukraine (draft). About the criminal code of Ukraine, New Penal Code, 02.01.2021. Recovered from: https://newcriminalcode.org.ua/upload/medi a/2021/01/04/kontrolnyj-proekt-kk-02-012021.pdf

Dorothy G. SK 13/05, Polish Constitution, for a declaration of non-compliance with art. 56 of the Law of September 10, 1999 - Fiscal Penal Code by virtue of art. 42 in relation to art. 2 of the Polish Constitution, 2015. Recovered from: https://trybunal.gov.pl/sprawy-wtrybunale/art/2013-deklaracje-podatkowe

Dudash, T.I. (2010). Legal understanding through the prism of hermeneutics. Lviv: Krai. 


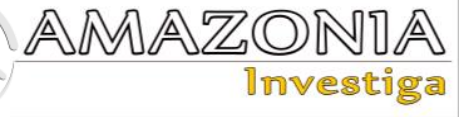

Dudchenko, V.V. (2014). Hermeneutics of law: the development of jurisprudence. Odessa: Phenix.

Ermakoff, I. (2020). Law against the Rule of Law: Assaulting Democracy. Journal of law and society, 47(S1), pp. 164-186. DOI: $10.1111 /$ jols. 12253

Iering, R. V. (2008). Legal Technique. ed. A.V. Polyakov. Moscow: Statut.

Inclusion Europe. (2009). European standards for making information easy to read and understand. Recovered from: http://inclusion-

europe.org/images/stories/documents/Project _Pathways1/Information_for_all.pdf

Kolmakova, V.V. (2009). The problem of interaction between legal and natural language. Legal Science and Teaching Methodology legal disciplines in the context of reforming the higher education system: a collection of scientific articles based on materials III International scientific-practical conference 10-11October 2008. Rostov on Don. Pp. 447-449.

Kophanov, L.L. (2008). Digests of Justinian. Moscow: Statut.

Kozachenko, O. V. and Musychenko, O.M. (2015). Cultural and anthropological dimension of justice of criminal legal influence: world achievements and national achievements. humanitarian discourse: politics, governance, power: collective monograph, by general editing O. A. Ivakin, I.V. Shamsha, D.V. Yakovlev. Odessa: Publishing House "Helvetika".

Kozachenko, O. V., Vasyliaka, O. K., Chornozub, L. V., \& Musychenko, O. M. (2020). Taxonomy of compulsory and incentive legal consequences (legal measures) of committing illegal acts. Cuestiones Políticas, 38(67), 151168. Recovered from: https://produccioncientificaluz.org/index.php /cuestiones/article/view/34688

Kozachenko, O., Sotula, O., Biblenko, V., Giulyakov, K., \& Bereznikov, O. (2021). El sustrato de la influencia penallegal. Cuestiones Políticas, 39(68), 441462. Recovered from: https://www.produccioncientificaluz.org/ind ex.php /cuestiones/article/view/35427/37787

Law 274. Plain Writing Act. 111th Congress Public plain, 13 October, 2010. Recovered from:

https://www.govinfo.gov/content/pkg/PLA W-111publ274/html/PLAW111publ274.htm
Law of Ukraine 3477-IV. On Enforcement of Judgments and Application of the Case Law of the European. Court of Human Rights, 23 February 2006 Available at: https://zakon.rada.gov.ua/laws/show/347715.

Montesquieu, Sh. (1956). Selected Works. Moscow : Gospolitizdat.

Mor, T. (1935). A golden book, as useful as it is funny, about the best statehood and the new island of Utopia. Moskov-Leningrad: Academia.

Musychenko, O.M. (2020). Intelligibility of criminal law (Dissertation PhD). Universidad Nacional "Odessa Law Academy", Odessa. Recovered from: http://dspace.onua.edu.ua/handle/11300/138 61

Novik v. Ukraine, Baranowski v. Poland, Khudoyorov v. Russia, SW v. The United Kingdom, Kokkinakis v. Greece, Ruban v. Ukraine, Mueller and others v. Switzerland, Salov v. Ukraine, Pasko v. Russia. European Court of Human Rights-Hudoc, database. Recovered from: https://hudoc.echr.coe.int/eng\#\{\%22docume ntcollectionid2\%22:[\%22GRANDCHAMB ER\%22,\%22CHAMBER\%22]\}

Order 12866. Regulatory Planning and Review, Federal register presidential documents. Vol. 58, No. 190. Executive of September 30, 1993. Recovered from: https://www.archives.gov/files/federalregister/executive-orders/pdf/12866.pdf .

Order 13563. Improving Regulation and Regulatory Review. Federal Register, 76(14), Executive of January 18, 2011. Recovered from:

https://www.govinfo.gov/content/pkg/FR2011-01-21/pdf/2011-1385.pdf .

Ovchinnikov, A.I. (2002). Legal thinking in the hermeneutic paradigm: monograph. Rostovon-Don: Rostov State Institute.

Ovsienko, L. (2013). Text as an object of study of psycholinguistics. Theoretical and didactic philology, No. 15. Pp.58-69.

Plain language (2011). Federal plain language guidelines. Recovered from: https://www.plainlanguage.gov/media/Feder alPLGuidelines.pdf.

Pogrebnyak, S.P. (2009). Fundamental principles of law. Dissertation. Kharkiv: Nat. jurid. acad. of Ukraine named after Yaroslav Mudry.

Public procurement. (2013). Entity initiating the proceedings: A group of deputies to the Sejm of the Republic of Poland. Available at: https://trybunal.gov.pl/sprawy-wtrybunale/art/2013-zamowienia-publiczne 
Pycheva, O.V. (2006). Hermeneutics of criminal law: dissertation. Ulyanovsk: Ulyanov. State University.

Real Decreto BOE-A-1889-4763. Código Civil. Texto consolidado. «Madrid Gazette» num. 206, de 25/07/1889. Recovered from: https://www.boe.es/buscar/act.php?id=BOEA-1889-4763 .

Resolution No. 2001-455 DC. Remission of 60 deputies of January 12, 2002. Recovered from: https://www.conseilconstitutionnel.fr/les-decisions/decision-n2001-455-dc-du-12-janvier-2002-saisinepar-60-deputes.

Romanov, A.K. (2015). Criminal law. Moscow: Delo.

Savigny, F.K. (2011). The system of modern Roman law, ed. O. Kutateladze and V. Zubar. Moscow: Statut.

Sentencia No. 1-r. Judgment of the Constitutional Court of Ukraine in the case of the constitutional petition of 59 deputies of Ukraine on compliance with the Constitution of Ukraine (constitutionality) of Article 3682 of the Criminal Code of Ukraine, Verkhovna Rada of Ukraine, February 26, $2019 . \quad$ Recovered from: https://zakon.rada.gov.ua/laws/show/v001p7 10-19\#n2 .

Sentencia No. 2-r. Judgment of the Constitutional Court of Ukraine in the case on the constitutional petition of 49 people of Deputies of Ukraine on the compliance of the Constitution of Ukraine (constitutionality) with paragraph 7 of part two of Article 42 of the Law of Ukraine 'On Higher education',
Verkhovna Rada of Ukraine, December 20, 2017 Recovered from: https://zakon.rada.gov.ua/laws/show/v002p7 10-17\#Text .

Sentencia No. 7-r. Judgment of the Constitutional Court of Ukraine in the case of the constitutional petition of 55 deputies of Ukraine on compliance with the Constitution of Ukraine (constitutionality) of Article 375 of the Criminal Code of Ukraine, Verkhovna Rada of Ukraine, June 1, 2020. Recovered from:

https://zakon.rada.gov.ua/laws/show/v007p7 10-20\#n2 .

Seryogin, S.V. (2014). The rule of law in Ukraine: problems of understanding and application: monograph. Dnipropetrovsk: Grani Publishing House.

Shargorodskii, M.D. (1948). Criminal Law Course. ch. 3. Moscow: Jurid. publishing house of the Ministry of Justice of the USSR, vol. 3.

Sitnikova, A.I. (2016).Criminal law textology: monograph. Moscow: Prospect.

Vekker, L.M. (1998). Psyche and reality: a unified theory of mental processes. Moscow: Smysl.

Venice. (2011). Report on the rule of law Adopted by the Venice Commission at its 86th plenary session, 25-26 March Recovered from: https://www.venice.coe.int/webforms/docum ents/?pdf=CDL-AD(2011)003rev-e .

Zaginej, Z.A. (2015). Criminal-legal hermeneutics: monograph. Kyiv: ArtEk Publishing House. 